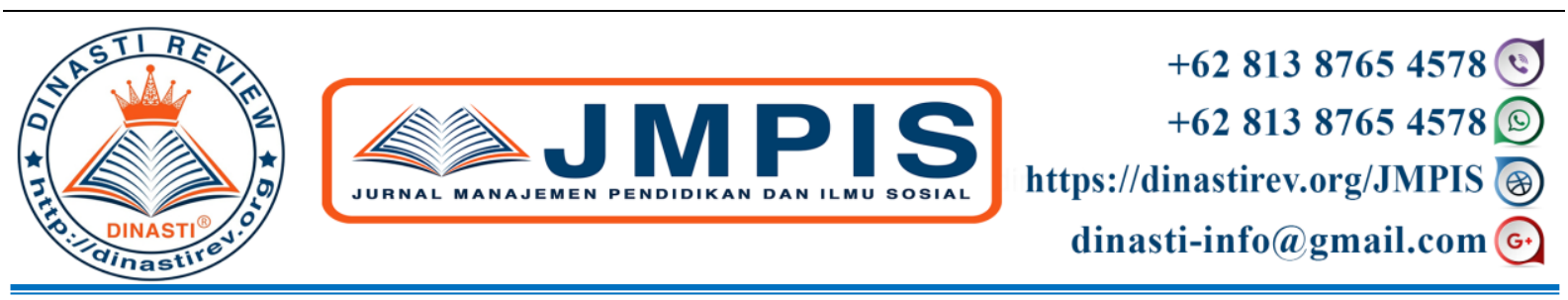

\title{
PENGARUH PENERAPAN MODEL PEMBELAJARAN PROBLEM BASED LEARNING (PBL) TERHADAP KEMAMPUAN BERPIKIR TINGKAT TINGGI (HOTS) DITINJAU DARI MOTIVASI BELAJAR SISWA
}

\author{
Suratno $^{1}$, Kamid ${ }^{2}$, Yulita Sinabang ${ }^{3}$ \\ 1) Dosen Universitas Jambi, Jambi, Indonesia \\ 2) Dosen Universitas Jambi, Jambi, Indonesia \\ 3) Alumni Program Studi Magister Pendidikan Universitas Jambi, Jambi, Indonesia
}

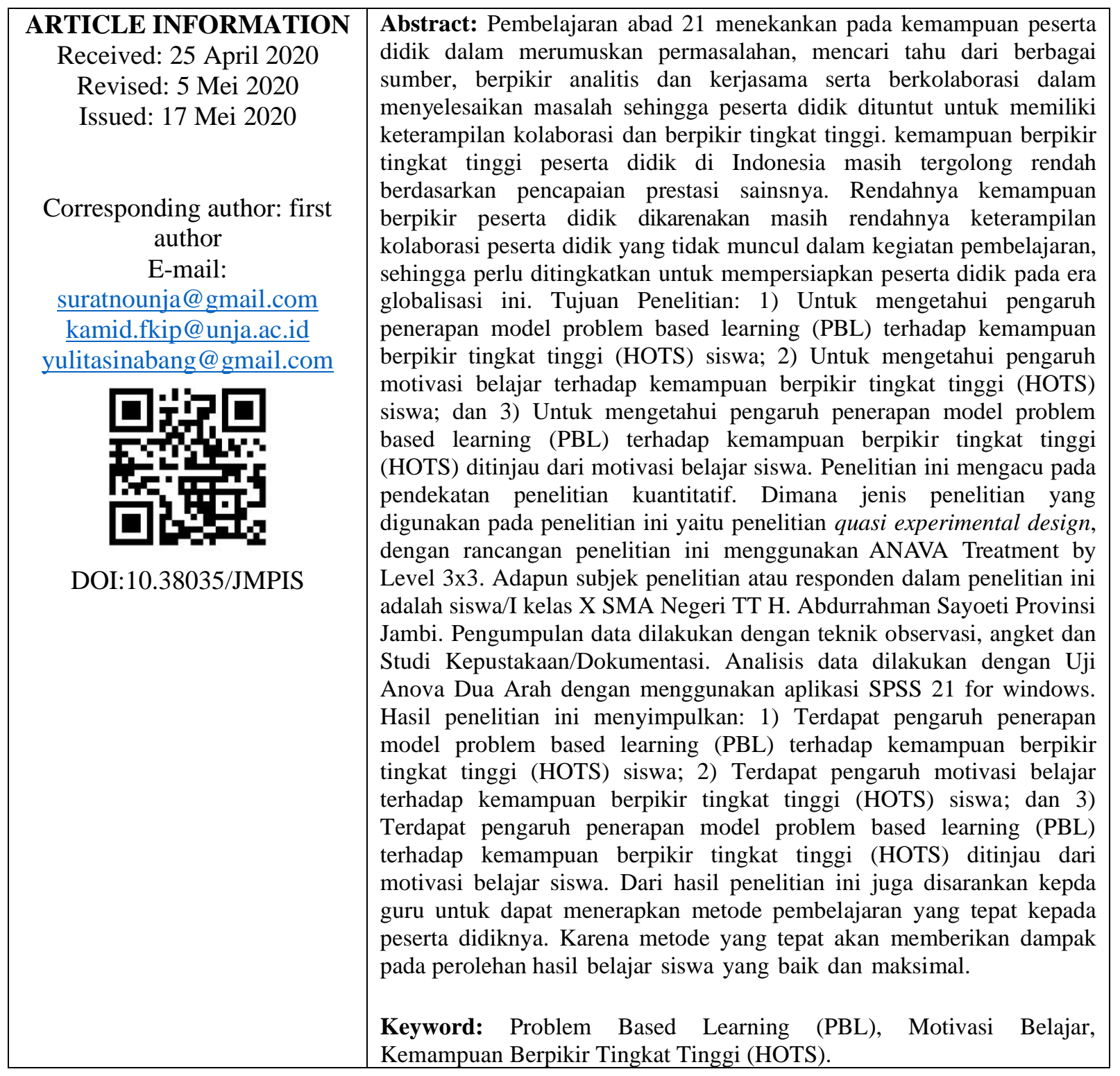




\section{PENDAHULUAN}

Pembelajaran abad 21 menekankan pada kemampuan peserta didik dalam merumuskan permasalahan, mencari tahu dari berbagai sumber, berpikir analitis dan kerjasama serta berkolaborasi dalam menyelesaikan masalah sehingga peserta didik dituntut untuk memiliki keterampilan kolaborasi dan berpikir tingkat tinggi, Yaitu sebuah pembelajaran yang menekankan pada kemampuan peserta didik dalam merumuskan permasalahan, mencari tahu dari berbagai sumber, berpikir analitis dan kerjasama serta berkolaborasi dalam menyelesaikan masalah sehingga.

Namun sayangnya faktanya pembelajaran yang diberikan selama ini masih belum ideal. Masih banyak sekolah yang menerapkan sistem pembelajaran yang bersifat teacher centered. Peserta didik hanya menerima informasi yang diberikan oleh pendidik, sehingga keterampilan kolaborasi peserta didik tidak akan muncul dalam kegiatan pembelajaran. Selain itu, keterampilan berpikir tingkat tinggi peserta didik di Indonesia masih tergolong rendah.

Rendahnya kemampuan berpikir peserta didik dikarenakan masih rendahnya Keterampilan kolaborasi peserta didik yang tidak muncul dalam kegiatan pembelajaran, sehingga perlu ditingkatkan untuk mempersiapkan peserta didik pada era globalisasi ini. Selain itu masih rendahnya kemampuan berpikir peserta didik juga dikarenakan Masih banyaknya guru menggunakan metode ceramah yang dilakukan secara konvensional dalam proses pembelajaran, dan menjadikan metode ceramah dalam proses pembelajaran sebagai pilihan utama para pendidik.

Sekolah Menengah Atas Negeri Titian Teras (SMAN TT) H. Abdurrahman Sayoeti Provinsi Jambi sendiri sebagai salah satu sekolah favorit yang ada di Provinsi Jambi, sejak awal dalam pelaksanaan proses belajar mengajar yang berlangsung memang sudah menerapkan keterampilan berpikir tingkat tinggi kepada peserta didiknya. Tujuan dari penerapan keterampilan berpikir kritis yang ada pada sekolah ini yakni agar peserta didiknya dapat mengembangkan keterampilan berpikir tingkat tinggi dan kolaborasi, sehingga peserta didiknya dapat aktif dalam proses belajar mengajar yang berlangsung.

Namun sayangnya, tidak semua peserta didik mampu mengikuti pola belajar (HOTS), terutama untuk kelas X (sepuluh) yang berasal dari daerah. Dimana siswa/I ini sebelumnya sudah terbiasa menggunakan metode belajar yang secara konvensional, kemudian berubah menggunakan metode belajar dengan keterampilan berpikir tingkat tinggi. Hal ini tentu saja akan merasa kesulitan, karena harus menyesuaikan metode belajarnya.

Secara teori terdapat banyak sekali faktor yang dapat mempengaruhi HOTS. Dimana salah satunya HOTS dapat di tingkatkan melalui model pembelajaran yang tepat. Menurut Bern dan Erikson dalam Komalasari (2011:23) terdapat lima model pembelajaran dalam mengimplementasikan pembelajaran yang mengaitkan materi yang diajarkan dengan situasi dunia nyata peserta didik yaitu 1) Problem based learning (pembelajaran berbasis masalah); 2) Cooperative learning (pembelajaran kooperatif); 3) Project based learning (pembelajaran berbasis proyek); 4) Service learning (pembelajaram pelayanan); dan 5) Work based learning (pembelajaran berbasis kerja).

Melihat begitu banyaknya jenis model pembelajaran tersebut, maka pada penelitian ini penulis mencoba untuk membandingkan penerapan model pembelajaran kooperatif Problem based learning (PBL), PBL beserta media dan konvensional beserta media. Model problem based learning $(P B L)$ merupakan salah satu model pembelajaran yang menunjang proses pembelajaran abad 21. Menurut Rusman (2012:229) $P B L$ merupakan pembelajaran yang dapat menyebabkan kemampuan berpikir peserta didik betul-betul dioptimalisasi melalui 
proses kerja kelompok atau tim yang sistematis, sehingga peserta didik dapat memperdayakan, mengasah, menguji, dan mengembangkan kemampuan berpikirnya secara berkesinambungan. Selain itu, Ngalimun (2013:90) menyatakan bahwa fokus pembelajaran pada model $P B L$ ada pada masalah yang dipilih sehingga peserta didik tidak saja mempelajari konsep-konsep yang berhubungan dengan masalah tetapi metode ilmiah untuk memecahkan masalah tersebut sehingga dapat menumbuhkan pola berpikir tingkat tinggi.

Pelaksanaan pembelajaran menggunakan model PBL tidak akan berjalan baik apabila siswa memiliki motivasi yang rendah. Hal ini sejalan dengan Arief, H.S., Maulana., dan Sudin, A (2016:141) yang menyatakan bahwa karena motivasi belajar memiliki peranan penting dalam pencapaian keberhasilan belajar di sekolah. Motivasi belajar perlu ditingkatkan kemudian diperlihara sehingga proses pembelajaran akan berjalan lancer dan tercapainya tujuan pembelajaran sesuai dengan harapan. Siswa yang termotivasi tinggi dalam belajar cenderung akan terlibat aktif dalam proses pembelajaran. Begitupun dengan siswa yang berhasil dalam belajar akan memiliki motivasi yang tinggi untuk terus belajar.

Berdasarkan dari penjabaran tersebut diatas maka penulis tertarik mengangkat tulisan ini menjadi sebuah penelitian dengan judul "Pengaruh Model Pembelajaran Problem Based Learning (PBL) Terhadap Kemampuan Berpikir Tingkat Tinggi (HOTS) Ditinjau dari Motivasi Belajar".

Berdasarkan permasalahan yang telah diuraikan sebelumnya, adapun tujuan-tujuan yang akan di capai dalam penelitian ini yaitu: 1) Untuk mengetahui pengaruh penerapan model problem based learning (PBL) terhadap kemampuan berpikir tingkat tinggi (HOTS) siswa; 2) Untuk mengetahui pengaruh motivasi belajar terhadap kemampuan berpikir tingkat tinggi (HOTS) siswa; dan 3) Untuk mengetahui pengaruh penerapan model problem based learning (PBL) terhadap kemampuan berpikir tingkat tinggi (HOTS) ditinjau dari motivasi belajar siswa.

\section{KAJIAN PUSTAKA}

\section{Model Pembelajaran Problem Based Learning (PBL)}

Problem Based Learning (PBL) merupakan salah satu model pembelajaran yang sesuai dan digalakkan dengan kurikulum 2013, dimana siswa dituntut untuk bersikap kritis, bekerja sama, cermat dalam menyelesaikan masalah, termotivasi dan percaya diri dalam memecahkan masalah nyata. Menurut Savery \& Duffy dalam Rahmayanti, E (2017:243) Problem Based Learning merupakan suatu model pembelajaran yang didasarkan pada masalah (problem) sebagai titik awal mendapatkan atau mengintegrasikan pengetahuan (knowledge) baru.

Problem Based Learning (PBL) merupakan salah satu model pembelajaran yang dapat menolong siswa untuk meningkatkan keterampilan yang dibutuhkan pada pada era globalisasi saat ini. Problem Based Learning (PBL) dikembangkan untuk pertama kali oleh Prof. Howard Barrows sekitar tahun 1970-an dalam pembelajaran ilmu medis di McMaster University Canada (Amir, 2009:124). Model pembelajaran ini menyajikan suatu masalah yang nyata bagi siswa sebagai awal pembelajaran kemudian diselesaikan melalui penyelidikan dan diterapkan dengan menggunakan pendekatan pemecahan masalah.

Ahmadi, A dan Widodo, S. (2013:33) menjelaskan bahwa dalam model Problem Based Learning, pembelajaran fokus pada masalah yang dipilih sehingga siswa tidak hanya mempelajari konsep-konsep yang berhubungan dengan masalah tetapi juga metode ilmiah dalam memecahkan masalah tersebut. Tujuannya untuk memperoleh kemampuan dan kecakapan kognitif dalam dalam memecahkan masalah secara rasional, lugas, dan tuntas.

Berdasarkan pendapat dari para ahli tersebut, maka dapat disintesiskan bahwa model pembelajaran PBL tersebut, penulis menyimpulkan bahwa model pembelajaran PBL adalah 
suatu model pembelajaran yang menggunakan masalah dunia nyata sebagai sesuatu yang harus dipelajari oleh siswa untuk melatih dan meningkatkan keterampilan berpikir kritis, bernalar, sekaligus pemecahan masalah, serta mendapatkan pengetahuan penting dari masalah tersebut. Dimana sintaks pembelajaran dalam model pembelajaran PBL melalui penilaian sikap, penilaian pengetahuan, dan penilaian diskusi. Tiga penilaian tersebut di rataratakan untuk mengetahui penilaian secara keseluruhan dari model yang diterapkan.

\section{Motivasi Belajar}

Motivasi belajar merupakan salah satu aspek psikis yang membantu dan mendorong seseorang untuk mencapai tujuannya. Maka motivasi harus ada dalam diri seseorang, sebab motivasi merupakan modal dasar untuk mencapai tujuan. Dengan demikian, motivasi harus menjadi pangkal permulaan dari pada semua aktivitas.

Menurut Slavin dalam Anni. C.T. (2008:156) mengemukakan bahwa motivasi merupakan proses internal yang mengaktifkan, memandu, dan memelihara perilaku seseorang secara terus-menerus. Sedangkan menurut Slameto (2010:170) menyatakan bahwa motivasi adalah suatu proses yang menentukan tingkah kegiatan, intensitas, konsistensi, serta arah umum dari tingkah laku manusia. Menurut Robbin dan Judge (2015:127) motivasi merupakan proses yang menjelaskan mengenai kekuatan, arah dan ketekunan seseorang dalam upaya untuk mencapai tujuan.

Motivasi dan belajar merupakan dua hal yang saling memengaruhi. Siswa akan giat belajar jika ia mempunyai motivasi untuk belajar. Thorndike mendefinisikan belajar sebagai proses interaski antara stimulus (yang mungkin berupa pikiran, perasaan, atau gerakan) dan respons. Pengertian ini senada dengan pendapat Goog dan Brophy yang menyatakan bahwa belajar merupakan suatu proses atau interaksi yang dilakukan seseorang dalam memperoleh sesuatu yang baru dalam bentuk perubahan perilaku sebagai hasil dari pengalaman belajar. Perubahan tingkah laku tersebut tampak dalam penguasaan siswa pada pola-pola tanggapan (respons) baru terhadap lingkungannya yang berupa keterampilan (skill), pengetahuan (knowledge), sikap atau pendirian (attitude), kemampuan (ability), pemahaman (understanding), emosi (emotion), apresiasi, jasmani, budi pekerti, serta hubungan social (Kompri, 2016:231).

Berdasarkan teori-teori tersebut di atas, dapat disintesiskan bahwa motivasi belajar adalah salah satu kunci utama untuk memperlancar dan menggairahkan siswa dalam mempelajari sesuatu. Motivasi merupakan segala sesuatu yang mendorong seseorang untuk melakukan sesuatu untuk memenuhi kebutuhan. Dari beberapa indicator yang telah dikemukakan di atas dapat disimpulkan bahwa terdapat dua aspek yang menjadi indikator pendorong motivasi belajar siswa, yaitu (1) dorongan internal: perhatian, minat, adanya hasrat dan keinginan belajar, dorongan dan kebutuhan dalam belajar, serta harapan dan citacita masa depan, dan (2) dorongan eksternal: metode belajar, alat pelajaran, dan kondisi lingkungan.

\section{High Order Thinking Skills (HOTS)}

HOTS atau keterampilan berpikir tingkat tinggi merupakan aspek penting dalam mengajar dan belajar. Keterampilan berpikir sangat penting dalam proses pendidikan. Orang berpikir dapat mempengaruhi kemampuan belajar, kecepatan, dan efektivitas belajar. Oleh karena itu, keterampilan berpikir ini dikaitkan dengan proses belajar. Peserta didik yang dilatih dengan berpikir menunjukkan dampak positif pada pengembangan pendidikan mereka (Heong dkk, 2011).

Menurut Rusyna (2014:136), dalam keterampilan berpikir, terdapat beberapa prinsip yang harus diperhatikan, yaitu: 1) Keterampilan berpikir tidak secara otomatis dapat dimiliki oleh peserta didik; 2) Keterampilan berpikir bukan merupakan hasil langsung dari pengajaran suatu bidang studi; 3) Pada kenyataannya peserta didik jarang melakukan transfer 
sendiri keterampilan berpikir ini, sehingga perlu adanya latihan terbimbing; dan 4) Pengajaran keterampilan berpikir memerlukan model pembelajaran yang berpusat kepada peserta didik (student centered).

Dalam taksonomi Bloom yang direvisi oleh Anderson dan Krathwohl, terdapat tiga aspek dalam ranah kognitif yang menjadi bagian dari kemampuan berpikir tingkat tinggi atau higher order thinking. Ketiga aspek tersebut yaitu aspek analisa, aspek evaluasi, dan aspek mencipta. Tiga aspek lain dalam ranah yang sama, yaitu aspek mengingat, aspek memahami, dan aspek aplikasi (menerapkan) masuk dalam bagian berpikir tingkat rendah atau lower order thinking (Suyono \& Hariyanto, 2014:167).

Berdasarkan dari teori-teori yang telah dikemukakan di atas, maka dapat disintesiskan bahwa kemampuan berpikir tingkat tinggi (Higher Order Thinking Skills) merupakan aktivitas berpikir yang tidak sekedar menghafal dan menyampaikan kembali informasi yang telah diketahui. Tetapi kemampuan berpikir tingkat tinggi juga merupakan kemampuan mengkonstruksi, memahami, dan mentransformasi pengetahuan serta pengalaman yang sudah dimiliki untuk dipergunakan dalam menentukan keputusan dan memecahkan suatu permasalahan pada situasi baru dan hal tersebut tidak dapat dipisahkan dari kehidupan seharihari.

\section{Kerangka Berpikir}

Kerangka ini didapatkan dari konsep ilmu atau teori yang dipakai sebagai landasan penelitian yang didapatkan pada tinjauan pustaka. Kerangka konseptual diharapkan akan memberikan gambaran dan mengarahkan asumsi mengenai variabel-variabel yang akan diteliti serta dapat memberikan petunjuk kepada peneliti di dalam merumuskan masalah penelitian. Penelitian ini menggunakan Quasi eksperimental design, yang terdiri dari tiga kelas. Dimana kelompok pertama adalah kelompok siswa yang mendapatkan perlakuan pembelajaran dengan model PBL, kelompok kedua adalah kelompok siswa yang mendapat perlakuan pembelajaran dengan model PBL beserta media, dan kelompok ketiga adalah kelompok siswa yang mendapat perlakuan pembelajaran dengan model Konvensional beserta Media. Adapun paradigma dari kerangka pemikiran dalam penelitian ini dapat dilihat pada Gambar 1 berikut:

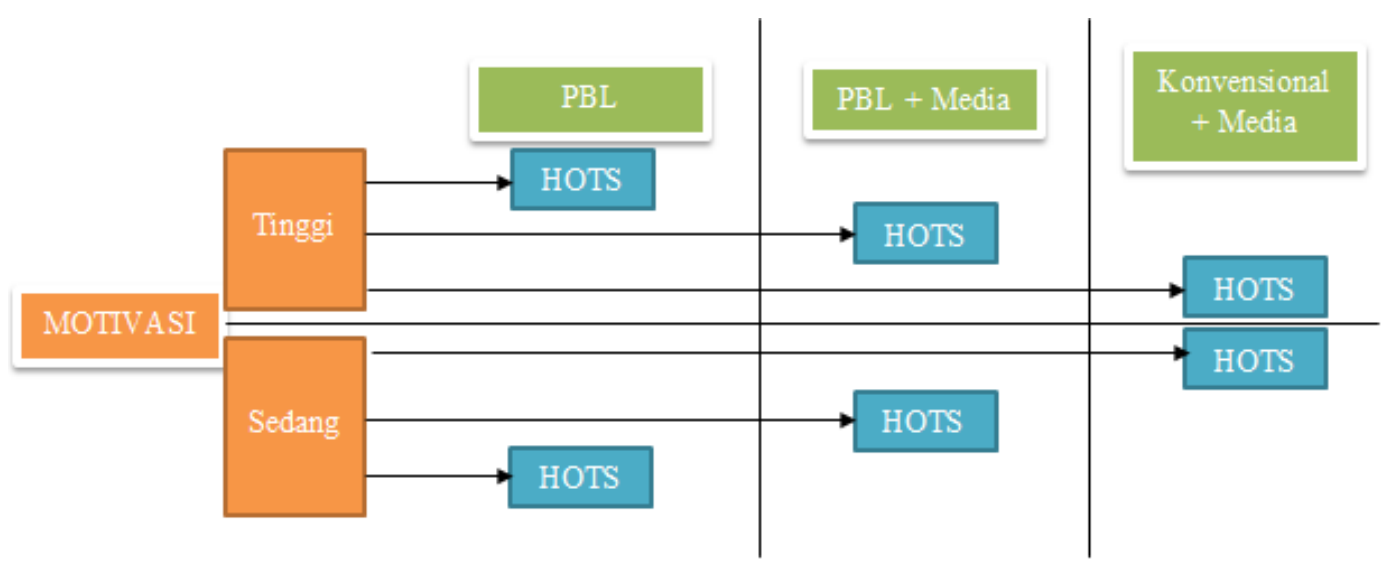

\section{Gambar 1 : Kerangka Pemikiran}

Berdasarkan pada kerangka pemikiran teoritis pada Gambar 1, maka hipotesis penelitian yang diajukan dalam penelitian ini adalah sebagai berikut:

1. $\mathrm{H}_{1}$. Penerpan model problem based learning (PBL) berpengaruh terhadap kemampuan berpikir tingkat tinggi (HOTS) siswa.

2. $\mathrm{H}_{1}$. Penerapan motivasi belajar berpengaruh terhadap kemampuan berpikir tingkat tinggi (HOTS) siswa. 
3. $\mathrm{H}_{1}$. Penerapan model problem based learning (PBL) berpengaruh terhadap kemampuan berpikir tingkat tinggi (HOTS) ditinjau dari motivasi belajar siswa.

\section{METODE PENELITIAN}

Penelitian ini mengacu pada pendekatan penelitian kuantitatif. Quasi eksperimental design digunakan dalam penelitian ini, karena partisipan/subjek eksperimen pada kelas control dan kelas eksperimen tidak dipilih secara acak. Pemilihan subjek dilakukan dengan teknik purposive sampling karena melalui pertimbangan tertentu.

Rancangan analisis penelitian ini adalah rancangan faktorial $3 \times 3$. Kelompok pertama adalah kelompok siswa yang mendapatkan perlakuan pembelajaran dengan model PBL, kelompok kedua adalah kelompok siswa yang mendapat perlakuan pembelajaran dengan model PBL beserta media, dan kelompok ketiga adalah kelompok siswa yang mendapat perlakuan pembelajaran dengan model Konvensional beserta Media. Dimana kelompok pertama dan kedua diberi perlakuan (X) dan kelompok yang lain tidak. Kelompok yang diberi perlakuan disebut kelompok eksperimen dan kelompok yang tidak diberi perlakuan disebut kelompok kontrol. Pengaruh adanya perlakuan (treatment) adalah $\left(\mathrm{O}_{1}: \mathrm{O}_{2}: \mathrm{O}_{3}\right)$. Kalau terdapat perbedaan yang signifikan antara kelompok eksperimen dan kelompok kontrol, maka perlakuan yang diberikan berpengaruh secara signifikan. Dalam penelitian ini, peneliti menggunakan metode eksperimen, yang bertujuan untuk mengetahui akan pengaruh atau akibat dari suatu perlakuan (treatment). Treatment yang dimaksud peneliti adalah model pembelajaran PBL, PBL beserta media dan Konvensional beserta Media. Jadi peneliti ingin mengetahui pengaruh model pembelajaran PBL, PBL beserta media dan Konvensional beserta Media. terhadap kemampuan berpikir tingkat tinggi (HOTS).

Penelitian ini sendiri dilakukan pada Sekolah Menengah Atas Titian Teras (SMAN TT) H. Abdurrahman Sayoeti Provinsi Jambi, yang terdiri dari tiga kelas. Dimana untuk kelompok pertama yaitu kelas IPS 1 adalah kelompok siswa yang mendapatkan perlakuan pembelajaran dengan model PBL sebanyak 27 siswa, kelompok kedua yaitu kelas IPS 2 adalah kelompok siswa yang mendapat perlakuan pembelajaran dengan model PBL beserta media sebanyak 25 siswa, dan kelompok ketiga yaitu kelas IPS 3 adalah kelompok siswa yang mendapat perlakuan pembelajaran dengan model Konvensional beserta media sebanyak 26 siswa, sehingga total subjek dalam penelitian ini yaitu sebanyak 78 siswa/i.

Sebelum dilakukan analisis lebih lanjut, terlebih dahulu dilakukan uji instrumen kuesioner dan uji prasyarat. Dimana uji instrument melalui uji validitas, reliabilitas, tingkat kesukaran soal, dan daya pembeda soal. Sedangkan uji prasyarat melalui uji normalitas dan uji homogenitas. Kemudian dilanjutkan dengan melakukan analisis uji Anova Dua Arah dan melakukan uji hipotesis melalui Chi Square.

\section{HASIL DAN PEMBAHASAN}

\section{Hasil Uji Prasyarat}

Dari hasil uji yang dilakukan dengan menggunkan bantuan SPSS 21.0 sebagai alat bantu dalam penelitian ini diperoleh hasil bahwasanya data dalam penelitian ini berdistribusi normal, hal ini dibuktikan dari hasil nilai signifikan model pembelajaran baik penerapan model PBL, penerapan PBL beserta media, model Konvensional beserta media, maupun motivasi belajar. Pada kolom shapiro wilk untuk model PBL diperoleh nilai sig sebesar 0,052, untuk model PBL beserta media diperoleh nilai sig sebesar 0,116, untuk model Konvensional beserta media dengan nilai sig sebesar 0,185 , dan untuk motivasi belajar diperoleh nilai sig sebesar 0,075, karena nilai sig > 0,05 maka dapat di ambil kesimpulan bahwa data sudah berdistribusi normal. 
Kemudian dari hasil uji homogenitas diperoleh nilai Sig 0,801 atau nilai sig ini > 0.05 (syarat homogenitas), artinya ketiga sampel mempunyai varians yang sama dan sudah memenuhi syarat uji Anova.

\section{Hasil Penelitian}

Dari eksperimen yang dilakukan, hasil belajar ekonomi yang diperoleh dikelompokkan sesuai dengan nama-nama siswa yang menjadi sampel dalam penelitian. Pada setiap kelas, baik kelas PBL, PBL beserta media maupun kelas Konvensional beserta media, terdapat tiga kelompok sampel berdasarkan motivasi belajarnya, seperti yang tampak pada output SPSS 21.0 for windows berikut.

Tabel 1. Rerata Kemampuan Berpikir Tingkat Tinggi (HOTS) Mata Pelajaran Ekonomi

\begin{tabular}{|c|c|c|c|c|}
\hline \multirow[b]{2}{*}{$\begin{array}{c}\text { Motivasi } \\
\text { Belajar }\end{array}$} & \multicolumn{3}{|c|}{ Model Pembelajaran } & \multirow[b]{2}{*}{ Jumlah Baris } \\
\hline & PBL (A1) & $\begin{array}{c}\text { PBL Beserta } \\
\text { Media (A2) }\end{array}$ & $\begin{array}{c}\text { Konvensional } \\
\text { Beserta } \\
\text { Media (A3) }\end{array}$ & \\
\hline $\begin{array}{c}\text { Tinggi } \\
\text { (B1) }\end{array}$ & $\begin{array}{l}\mathrm{n}_{1}=15 \\
\bar{x}_{1}=80,59\end{array}$ & $\begin{array}{l}\mathrm{n}_{2}=18 \\
\bar{x}_{2}=83,17\end{array}$ & $\begin{array}{l}\mathrm{n}_{3}=13 \\
\bar{x}_{3}=74,88\end{array}$ & $\begin{array}{l}\mathrm{n}_{\mathrm{b} 1}=46 \\
\bar{x}_{b 1}=79,99\end{array}$ \\
\hline $\begin{array}{l}\text { Sedang } \\
\text { (B2) }\end{array}$ & $\begin{array}{l}\mathrm{n}_{4}=12 \\
\bar{x}_{1}=65,93\end{array}$ & $\begin{array}{l}\mathrm{n}_{5}=7 \\
\bar{x}_{2}=68,49\end{array}$ & $\begin{array}{l}\mathrm{n}_{6}=13 \\
\bar{x}_{3}=63,12\end{array}$ & $\begin{array}{l}\mathrm{n}_{\mathrm{b} 2}=32 \\
\bar{x}_{b 2}=65,35\end{array}$ \\
\hline $\begin{array}{c}\text { Jumlah } \\
\text { Kolom } \\
\end{array}$ & $\begin{array}{l}\mathrm{n}_{\mathrm{k} 1}=27 \\
\bar{x}_{k 1}=74,07\end{array}$ & $\begin{array}{l}\mathrm{n}_{\mathrm{k} 2}=25 \\
\bar{x}_{k 2}=79,06\end{array}$ & $\begin{array}{l}\mathrm{n}_{\mathrm{k} 3}=26 \\
\bar{x}_{k 3}=69\end{array}$ & $\begin{array}{l}\mathrm{n}_{\mathrm{t}}=78 \\
\bar{x}_{t}=73,98\end{array}$ \\
\hline
\end{tabular}

Sumber: Data diolah, 2020.

Dari rerata kemampuan berpikir tingkat tinggi (HOTS) mata pelajaran ekonomi seperti yang tampak pada tabel di atas, dapat diketahui bahwa kelas eksperimen yang terdiri dari kelas X IPS 1 (PBL) dan kelas X IPS 2 (PBL beserta media) lebih unggul dibandingkan dengan control yang menggunakan model Konvensional beserta media. Dimana penerapan model PBL beserta media lebih baik dibandingkan dengan 2 model lainnya yaitu model PBL dan model Konvensional beserta media. Baik itu dilihat dari hasil belajar motivasi tinggi maupun motivasi rendah model pembelajaran tipe PBL beserta media lebih unggul bila dibandingkan dengan model PBL dan model Konvensional beserta media.

Berikut ini dapat dilihat hasil uji Uji Analisis Dua Jalur (two way ANOVA) yang disajikan pada Tabel 5.

Tabel 2. Uji Analisis Dua Jalur (two way ANOVA)

Tests of Between-Subjects Effects

Dependent Variable: Z_HOTS

\begin{tabular}{|l|r|r|r|r|r|}
\hline Source & $\begin{array}{c}\text { Type III Sum } \\
\text { of Squares }\end{array}$ & Df & Mean Square & \multicolumn{1}{c|}{ F } & \multicolumn{1}{c|}{ Sig. } \\
\hline Corrected Model & $4706,358^{\mathrm{a}}$ & 5 & 941,272 & 22,253 &, 000 \\
Intercept & 378807,966 & 1 & 378807,966 & 8955,429 &, 000 \\
X_Model_Pembelajaran & 556,560 & 2 & 278,280 & 6,579 &, 002 \\
Y_Motivasi_Belajar & 3362,902 & 1 & 3362,902 & 79,503 &, 000 \\
X_Model_Pembelajaran & 35,217 & 2 & 17,608 &, 416 &, 661 \\
*Y_Motivasi_Belajar & & & & \\
Error & 3045,546 & 72 & 42,299 & & \\
Total & 434671,250 & 78 & & & \\
Corrected Total & 7751,904 & 77 & & & \\
\hline
\end{tabular}

a. R Squared $=, 607$ (Adjusted R Squared $=, 580$ )

Dari Tabel di atas merupakan hasil akhir dari uji two way anova. Berikut penjelasanya: 


\section{$>$ Corrected Model}

Dari koreksi model ini kita dapat mengetahui seberapa besar pengaruh variabel independent (variabel bebas) terhadap variable dependent (variable terikat). Dalam hal ini variabel independent yaitu faktor-faktor yang akan di ukur oleh peneliti (Model Pembelajaran, Motivasi Belajar dan Model Pembelajaran*Motivasi Belajar) untuk menentukan hubungan antara variable dependent (nilai yang akan di amati). Dari tabel di atas bisa kita lihat berdasarkan nilai (sig) yang diperoleh $<0,05$ yaitu $(0,000<$ $0,05)$ berarti model yang diperoleh valid.

\section{$>$ Intercept}

Nilai intercept dalam hal ini merupakan nilai siswa pada variabel nilai yang berkontribusi pada nilai itu sendiri tanpa dipengaruhi oleh variabel independent, artinya berubah nilai pada variabel dependent tidak ada pengaruh sedikit pun oleh variabel independent. Dari tabel di atas bisa kita lihat berdasarkan nilai (sig), bila niai sig $<0,05$ yaitu $(0,000<0,05)$ berarti intercept ini berkontribusi secara signifikan. Hal ini menjelaskan bahwasanya nilai HOTS masih dapat berubah tanpa ada pengaruh nilai variabel model pembelajaran dan motivasi belajar. Hal ini dapat berupa minat belajar, lingkungan keluarga, lingkungan sekolah, lingkungan teman sebaya, maupun faktor-faktor lainnya yang tidak di kaji dalam penelitian ini.

$>$ Model_Pembelajaran

Berpengaruh atau tidaknya model pembelajaran terhadap HOTS ditandai dari nilai signifikan, dari tabel di atas diperoleh nilai sig 0,002. Dikarenakan nilai signifikan jauh lebih kecil dari $0,05,(0,002<0,05)$ maka dapat disimpulkan model pembelajaran berpengaruh signifikan terhadap HOTS siswa.

$>$ Motivasi_Belajar

Berpengaruh atau tidaknya Motivasi belajar terhadap HOTS ditandai dari nilai signifikan, dari tabel di atas diperoleh nilai sig 0,000. Dikarenakan nilai signifikan jauh lebih kecil dari 0,05 , $(0,000<0.05)$ maka dapat disimpulkan motivasi belajar berpengaruh signifikan terhadap HOTS siswa.

$>$ Model_Pembelajaran*Motivasi_Belajar

Uji ini bertujuan untuk mengetahui apakah ada hubungan yang signifikan antara dua faktor, dalam kasus ini kita akan menguji ada atau tidaknya interaksi antara model pembelajaran dengan motivasi belajar. Dari tabel di atas terlihat bahwa nilai $\mathrm{F}$ hitung 0,416 dan $\mathrm{F}$ tabel 3,12 (F tabel lihat tabel distribusi $\mathrm{F}$ untuk anova) atau nilai signifikan yang di peroleh dari tabel di atas sebesar 0,416. Jadi dapat disimpulkan: tidak ada interaksi antara model pembelajaran terhadap motivasi belajar. Karena tidak ada interaksi antara model pembelajaran terhadap motivasi belajar, maka tidak perlu uji lanjut Post Hoc.

\section{Pengujian Hipotesis Chi Square}

Pengujian hipotesis dalam penelitian ini dilakukan melalui Uji Chi Square. Dasar pengambilan keputusan dalam uji chi square dapat dialkukan dengan melihat nilai output "Chi Square Test" hasil olah data dengan SPSS. Dalam pengambilan keputusan kita dapat berpedoman pada hal, yakni membandingkan nilai Asymp. Sig dengan batas kritis yakni 0,05 (5\%). Berikut ini dapat dilihat output Chi Square dari proses pengolahan data yang dilakukan dengan SPSS sebagai berikut.

Tabel 3. Uji Analisis Chi Square Model Pembelajaran Dengan HOTS Chi-Square Tests 


\begin{tabular}{|l|r|r|r|}
\hline & \multicolumn{1}{|c|}{ Value } & \multicolumn{1}{|c|}{ Df } & Asymp. Sig. (2-sided) \\
\hline Pearson Chi-Square & $42,894^{\mathrm{a}}$ & 28 &, 036 \\
Likelihood Ratio & 50,502 & 28 &, 006 \\
Linear-by-Linear & 3,263 & 1 &, 071 \\
Association & 78 & & \\
N of Valid Cases & & \\
\hline
\end{tabular}

a. 45 cells $(100,0 \%)$ have expected count less than 5 . The minimum expected count is, 32 .

Dari hasil analisis Chi Square pada Tabel 3 diatas dengan menggunakan SPSS 21.0 diperoleh nilai sig 0,036. Karena nilai Asymp.Sig 0,036 <0,05, maka dapat disimpulkan bahwa $\mathrm{H}_{1}$ diterima dan menolak $\mathrm{H}_{0}$, yang artinya terdapat hubungan antara model pembelajaran dengan HOTS. Hal ini dapat diartikan pula bahwa model pembelajaran yang baik mempunyai korelasi dengan HOTS peserta didik.

Tabel 4. Uji Analisis Chi Square Motivasi Belajar Dengan HOTS Chi-Square Tests

\begin{tabular}{|l|r|r|r|}
\hline & \multicolumn{1}{|c|}{ Value } & \multicolumn{1}{|c|}{ Df } & Asymp. Sig. (2-sided) \\
\hline Pearson Chi-Square & $51,013^{\mathrm{a}}$ & 14 &, 000 \\
Likelihood Ratio & 64,834 & 14 &, 000 \\
Linear-by-Linear & 40,156 & 1 &, 000 \\
Association & & & \\
N of Valid Cases & 78 & & \\
\hline
\end{tabular}

a. 28 cells $(93,3 \%)$ have expected count less than 5 . The minimum expected count is, 41 .

Dari hasil analisis Chi Square pada Tabel 4 diatas dengan menggunakan SPSS 21.0 diperoleh nilai sig 0,000. Karena nilai Asymp.Sig 0,000<0,05, maka dapat disimpulkan bahwa $\mathrm{H}_{1}$ diterima dan menolak $\mathrm{H}_{0}$, yang artinya terdapat hubungan antara motivasi belajar dengan HOTS. Hal ini dapat diartikan pula bahwa motivasi belajar yang tinggi mempunyai korelasi dengan HOTS peserta didik.

\section{Pembahasan}

Berdasarkan dari pengujian hipotesis yang dilakukan diperoleh hasil bahwasanya model pembelajaran dan motivasi belajar berpengaruh terhadap HOTS siswa-siswa, secara rinci akan dibahas satu persatu sebagai berikut:

\section{Temuan Pertama}

Dari pengujian hipotesis yang dilakukan diketahui bahwa penerapan model pembelajaran Problem Based Learning (PBL) berpengaruh terhadap kemampuan berpikir tingkat tinggi (HOTS). Dimana dari hasil penelitian yang dilakukan diketahui bahwa kemampuan berpikir tingkat tinggi (HOTS) siswa yang menggunakan model pembelajaran PBL lebih baik dibandingkan dengan kemampuan berpikir tingkat tinggi siswa yang menggunakan model konvensional. Hal ini dapat dilihat dari respon peserta didik yang cenderung terlihat lebih aktif pada kelas eksperimen dengan menggunakan model PBL maupun PBL beserta media dibandingkan dengan menggunakan model Konvensional beserta media pada kelas kontrol.

Dimana hal ini dapat dilihat dari hasil rerata hasil belajar yang diketahui kemampuan berpikir tingkat tinggi (HOTS) kelas eksperimen lebih baik dibandingkan dengan kelas control. Baik itu dilihat dari motivasi tinggi maupun motivasi sedangnya. Kelas eksperimen yang terdiri dari kelas X IPS 1 (PBL) dan kelas X IPS 2 (PBL beserta media) lebih baik dibandingkan dengan kelas konrol IPS 3 yang menggunakan model Konvensional beserta 
media. Namun bila dibandingkan antara kedua kelas eksperimen yaitu kelas X IPS 1 (PBL) dan kelas X IPS 2 (PBL beserta media), kelas X IPS 2 memiliki nilai yang lebih baik, karena kelas ini menambahkan media untuk mendukung pembelajarannya. Hal ini dapat dilihat dari nilai rerata yang diperoleh yakni dimana rerata model PBL beserta media motivasi tinggi sebesar 83,17, sedangkan rerata model PBL motivasi tinggi sebesar 80,59 dan Konvensional beserta media motivasi tinggi sebesar 74,88. Begitu pula bila dilihat dari motivasi sedangnya diketahui bahwa PBL beserta media juga lebih unggul dibandingkan dengan dua model lainnya, dimana nilai yang diperoleh untuk motivasi sedangnya yaitu sebesar 68,49, sedangkan untuk rerata model PBL motivasi sedang sebesar 65,93 dan Konvensional beserta media motivasi sedang sebesar 63,12.

Hasil penelitian ini menunjukan hasil yang sama dengan penelitian yang dilakukan oleh Royantoro, F., Mujasam., Yusuf, I., Widyaningsih, S.W (2018), Flamboyant, F.U., Murdani, E., \& Soeharto (2018), dan Kurniawati, T (2019), dimana hasil penelitiannya menunjukan bahwa peserta didik yang diajarkan dengan medel PBL memiliki pengaruh yang signifikan terhadap HOTS peserta didik. Selain itu hasil penelitian ini sejalan dengan penelitian yang dilakukan oleh Widiawati, L., Joyoatmojo, S., and Sudiyanto, S (2018), yang mengemukakan bahwa Problem Based Learning yang terintegrasi mampu meningkatkan keterampilan berpikir tingkat tinggi belajar siswa dibandingkan dengan pendekatan ilmiah dalam ThinkPair.

Selanjutnya Tam, N.T.M. (2018) dalam penelitiannya juga menjelaskan bahwa pendekatan pembelajaran berbasis masalah (PBL) dapat meningkatkan keterampilan berpikir siswa dan memfasilitasi pembelajaran siswa, karena kegiatan pembelajaran berbasis masalah yang mengharuskan siswa menggunakan keterampilan berpikir tingkat tinggi (HOTS) dalam pembelajaran mereka. Sejalan dengan penelitian yang dilakukan oleh Simanungkalit, I., Utanto, Y., and Rifai, A (2019) yang mengemukakan bahwa ada interaksi antara HOTS berbasis PBL dengan HOTS Berbasis Pembelajaran Penemuan dengan hasil belajar siswa. Dimana hasil pembelajaran menggunakan HOTS Berbasis PBL-HOTS telah mampu meningkatkan nilai pre-test dan post-test dalam penelitian ini.

Pembelajaran berbasis masalah (PBL) menurut Adiga, U and Adiga S (2015) merupakan strategi kurikuler komprehensif yang mendorong pembelajaran yang berpusat pada siswa dan keterampilan yang diinginkan. PBL adalah cara yang efektif untuk memberikan pendidikan terpadu, serta menawarkan beberapa keunggulan dibandingkan metode pengajaran tradisional. Ini didasarkan pada prinsip-prinsip teori pembelajaran orang dewasa, termasuk memotivasi siswa, mendorong mereka untuk menetapkan tujuan belajar mereka sendiri, dan memberi mereka peran dalam keputusan yang mempengaruhi pembelajaran mereka sendiri.

\section{Temuan Kedua}

Dari pengujian hipotesis yang dilakukan diketahui bahwa motivasi belajar memiliki pengaruh terhadap kemampuan berpikir tingkat tinggi (HOTS) siswa. Dimana dari kajian yang dilakukan diketahui bahwa secara rata-rata, kemampuan berpikir tingkat siswa yang memiliki motivasi belajar yang tinggi pada mata pelajaran ekonomi dan dengan menggunakan model pembelajaran PBL memiliki nilai yang lebih tinggi, daripada siswa yang memiliki motivasi belajar tinggi dan diajarkan dengan menggunakan model pembelajaran secara konvensional.

Berdasarkan dari tindakan yang dilakukan diperoleh bahwa siswa yang memiliki motivasi belajar tinggi pada mata pelajaran ekonomi akan memperoleh HOTS yang lebih baik, daripada siswa yang memiliki motivasi belajar yang rendah pada mata pelajaran ekonomi cenderung memiliki HOTS yang rendah. Hal ini dapat diartikan, cenderung siswa yang memiliki motivasi belajar yang tinggi akan memperoleh HOTS yang tinggi pula, 
sedangkan cenderung siswa yang memiliki motivasi belajar yang rendah akan memperoleh HOTS yang rendah.

Motivasi siswa mengacu pada sejauh mana siswa berusaha dan fokus pada pembelajaran untuk mencapai hasil yang sukses. Motivasi dan keterlibatan sangat penting untuk pembelajaran siswa yang sehat. Sternberg dalam Saeed, S., \& David Zyngier, D (2012) percaya bahwa motivasi sangat penting untuk keberhasilan sekolah, jika tidak ada; siswa tidak pernah berusaha untuk belajar

Motivasi pada dasarnya berkaitan dengan motivasi intrinsik dan ekstrinsik pada berbagai jenis keterlibatan siswa. Para siswa yang lebih menyukai motivasi ekstrinsik juga menunjukkan bentuk-bentuk keterlibatan ritual dan retretis dan para siswa yang menunjukkan motivasi intrinsik dan ekstrinsik menunjukkan keterlibatan yang otentik, ritual, retretist, dan pemberontak. Selain itu motivasi intrinsik juga membantu keterlibatan siswa otentik dalam pembelajaran. sedangkan motivasi ekstrinsik berfungsi untuk mengembangkan keterlibatan ritual pada siswa, siswa yang memiliki kedua jenis motivasi menunjukkan berbagai jenis keterlibatan dalam pembelajaran mereka (Saeed, S., \& David Zyngier, D., 2012).

\section{Temuan Ketiga}

Dari hasil penelitian yang dilakukan diketahui bahwa terdapat perbedaan hasil belajar antara siswa yang diajar dengan model PBL dengan siswa yang diajar dengan model pembelajaran konvensional ditinjau dari motivasi siswa. Ditinjau dari siswa yang memiliki motivasi tinggi, hasil belajar antara siswa yang diajar dengan metode Problem Based Learning lebih tinggi dibandingkan dengan siswa yang diajar dengan metode pembelajaran konvensional. Ditinjau dari siswa yang memiliki motivasi rendah, hasil belajar antara siswa yang diajar dengan metode PBL lebih tinggi dibandingkan dengan siswa yang diajar dengan metode pembelajaran konvensional.

Motivasi belajar adalah dorongan internal dan eksternal pada siswa yang sedang belajar utuk mengadakan perubahan tingkah laku, pada umumnya dengan beberapa indikator atau unsur yang mendukung. Hal itu memepengaruhi peran besar keberhasilan belajar (Hamzah B. Uno dalam Hamzah, I.N., Imron, A., dan Ekwandari, Y.S., 2016).

Motivasi diartikan sebagai tenaga dalam diri manusia yang akan mendorong seseorang untuk mencapai prestasi sesuai dengan standar yang telah ditetapkan. Motivasi merupakan kebutuhan untuk melakukan dengan baik atau berjuang untuk sukses, dan dibuktikan dengan ketekunan dan usaha dalam mengadapi kesulitan, motivasi dianggap sebagai dorongan yang berasal dari dalam diri manusia. Menurut Pamuja motivasi dapat menjadi faktor psikologis yang berfungsi mendasari, menimbulkan, dan mengarah dalam menghadapi masalah atau ketika dalam belajar, dalam artian ketika dalam pembelajaran siswa dengan motivasi tinggi akan selalu berusaha tampak gigih, serta giat dalam belajar, dan sebaliknya siswa dengan motivasi belajar rendah, akan tampak acuh tak acuh, mudah putus asa serta perhatiannya kurang dalam pembelajaran (Fitri, H., Dasna, I.W., \& Suharjo, 2018:207).

Motivasi belajar siswa berpengaruh dalam kegiatan belajar dengan kemampuan berpikir tingkat tinggi. Siswa dengan motivasi belajar tinggi akan terlihat antusias mengikuti pembelajaran yang diberikan oleh guru yang melatih siswa dalam kemampuan berpikir tingkat tinggi. Hal ini sejalan dengan penelitian yang dilakukan Fitri, H., Dasna, I.W., \& Suharjo (2018:206), yang menyatakan bahwa kemampuan berpikir tingkat tinggi siswa yang memiliki motivasi tinggi lebih baik dari pada siswa yang memiliki motivasi rendah.

\section{KESIMPULAN DAN SARAN}

Kesimpulan: 1) Terdapat pengaruh penerapan model problem based learning (PBL) terhadap kemampuan berpikir tingkat tinggi (HOTS) siswa. Dimana terdapat perbedaan 
kemampuan berpikir tingkat tinggi yang signifikan antara siswa yang diajar dengan model PBL dengan siswa yang diajar dengan metode pembelajaran konvensional. Kemampuan berpikir tingkat tinggi siswa siswa yang diajar dengan metode PBL lebih tinggi dibandingkan dengan siswa yang diajar dengan metode pembelajaran konvensional; 2) Terdapat pengaruh motivasi belajar terhadap kemampuan berpikir tingkat tinggi (HOTS) siswa. Dimana berdasarkan hasil penelitian yang dilakukan diperoleh bahwa siswa yang memiliki motivasi belajar tinggi pada mata pelajaran ekonomi akan memperoleh HOTS yang lebih baik, daripada siswa yang memiliki motivasi belajar yang rendah pada mata pelajaran ekonomi cenderung memiliki HOTS yang rendah. Hal ini dapat diartikan, cenderung siswa yang memiliki motivasi belajar yang tinggi akan memperoleh HOTS yang tinggi pula, sedangkan cenderung siswa yang memiliki motivasi belajar yang rendah akan memperoleh HOTS yang rendah; dan 3) Terdapat pengaruh penerapan model problem based learning (PBL) terhadap kemampuan berpikir tingkat tinggi (HOTS) ditinjau dari motivasi belajar siswa. Dimana berdasarkan hasil penelitian yang dilakukan diketahui bahwa terdapat perbedaan kemampuan berpikir tingkat tinggi yang signifikan antara siswa yang diajar dengan metode PBL dengan siswa yang diajar dengan metode pembelajaran konvensional ditinjau dari motivasi siswa. Ditinjau dari siswa yang memiliki motivasi tinggi, kemampuan berpikir tingkat tinggi antara siswa yang diajar dengan metode Problem Based Learning lebih tinggi dibandingkan dengan siswa yang diajar dengan metode pembelajaran konvensional. Ditinjau dari siswa yang memiliki motivasi sedang, kemampuan berpikir tingkat tinggi antara siswa yang diajar dengan metode $P B L$ lebih tinggi dibandingkan dengan siswa yang diajar dengan metode pembelajaran konvensional.

Saran: 1) Bagi Guru, penerapan metode pembelajaran oleh seorang guru yang tepat akan memberikan dampak pada perolehan hasil belajar siswa yang baik dan maksimal. Meskipun hasil belajar yang baik dan maksimal tidak sepenuhnya ditentukan oleh penggunaan metode pembelajaran akan tetapi guru harus memahami metode pembelajaran baik secara konseptual maupun praktikal. Penelitian ini menunjukkan bahwa pemilihan penerapan metode pembelajaran yang sesuai akan lebih efektif dan maksimal dalam meningkatkan hasil belajar; 2) Diharapkan seorang guru dapat memotivasi siswa untuk dapat lebih memperhatikan dalam setiap materi sehingga dapat lebih meningkatkan hasil belajar siswa khususnya pada mata pelajaran ekonomi.; 3) Kedepan diharapkan guru dalam upaya meningkatkan motivasi belajar siswa, guru hendaknya dapat menjelaskan hal-hal yang menarik dan berguna bagi kehidupan siswa serta terkait dengan bahan pelajaran yang sedang dipelajari sehingga dapat mengoptimalkan kemampuan berpikir tingkat tinggi siswa; 4) Bagi siswa diharapkan agar lebih aktif bertanya ketika pembelajaran berlangsung dan mengerjakan latihan meskipun tidak akan ditunjuk oleh guru sehingga hasil belajar akan lebih optimal; dan 5) Dalam penelitian ini masih banyak kekurangan, terutama pada terbatasnya referensi untuk bahan ajar. Diharapkan ada pihak lain yang meneruskan penelitian ini dengan menambah referensi bahan ajar agar mendapatkan perangkat pembelajaran yang lebih baik untuk meningkatkan kualitas pembelajaran.

\section{DAFTAR RUJUKAN}

Adiga, U and Adiga S. 2015. Problem Based Learning. International Journal of Current Research, Vol. 7, Issue 06.

Ahmadi, A dan Widodo, S. 2013. Psikologi Belajar. Jakarta : PT Rineka Cipta

Amir, Taufiq. 2009. Inovasi Pendid ikan Melalui Problem Based Learning. Jakarta: Kencana Prenada Media Group.

Anni, C.T. 2008. Psikologi Belajar. Semarang: Unnes Press. 
Arief, H.S., Maulana., \& Sudin, A. 2016. Meningkatkan Motivasi Belajar Melalui Pendekatan Problem-Based Learning (PBL). Jurnal Pena Ilmiah, Vol. 1, No.1.

Fitri, H., Dasna, I.W., \& Suharjo. 2018. Pengaruh Model Project Based Learning (PjBL) Terhadap Kemampuan Berpikir Tingkat Tinggi di Tinjau dari Motivasi Berprestasi Siswa Kelas IV Sekolah Dasar. BRILIANT: Jurnal Riset dan Konseptual, Volume 3, Nomor 2.

Flamboyant, F.U., Murdani, E., \& Soeharto. 2018. Pengaruh Model Problem Based Learning Terhadap Higher Order Thinking Skills Peserta Didik SMA Negeri di Kota Singkawan pada Materi Hukum Archimedes. Variabel, Vol. 1, No. 2.

Hamzah, I.N., Imron, I., \& Ekwandari, Y.S. 2016. Pengaruh Model Project Based Learning (PjBL) Terhadap Peningkatan Motivasi Belajar Sejarah Siswa.

Heong, Y.M., dkk. 2011. The Level of Marzano Higher Order Thinking Skills Among Technical Education Students. International Journal of Social and Humanity, Vol. 1, No. 2, July 2011, 121-125.

Komalasari, Kokom. 2011. Pembelajaran Kontekstual. Bandung: Refika Aditama.

Kompri. (2016). Motivasi Pembelajaran: Perspektif Guru dan Siswa. Bandung: Remaja Rosdakarya.

Kurniawati, T. 2019. Improving Students' Higher Order-thinking Skills Through Problembased Learning in Introduction to Microeconomics Course. KnE Social Sciences.

Rahmayanti, E. 2017. Penerapan Problem Based Learning dalam Meningkatkan Kritis Peserta Didik pada Pembelajaran Pendidikan Pancasila dan Kewarganegaraan Kelas XI SMA. Prosiding Konferensi Nasional Kewarganegaraan III.

Robbins, S.P dan Judge, T.A. 2015. Perilaku Organisasi. Jakarta: Salemba Empat.

Royantoro, F., Mujasam., Yusuf, I., Widyaningsih, S.W. 2018. Pengaruh Model Problem Based Learning Terhadap Higher Order Thinking Skills Peserta Didik. Berkala Ilmiah Pendidikan Fisika, Vol. 6, No. 3.

Rusman. 2012. Model-Model Pembelajaran Mengembangkan Profesionalisme Guru. Jakarta: Rajawali Pers.

Rusyna, A. 2014. Keterampilan Berpikir: Pedoman Praktis Para Peneliti Keterampilan Berpikir. Yogyakarta: Penerbit Ombak.

Saeed, S., \& David Zyngier, D. 2012. How Motivation Influences Student Engagement: A Qualitative Case Study. Journal of Education and Learning; Vol. 1, No. 2.

Simanungkalit, I., Utanto, Y., and Rifai, A. 2019. The Effectiveness of PBL-Based HOTS in English Learning. Innovative Journal of Curriculum and Educational Technology, Vol. 8, No. 2.

Slameto. 2010. Belajar dan Faktor-faktor yang mempengaruhinya. Jakarta: PT. Rineka Cipta.

Suyono \& Hariyanto. 2014. Belajar dan Pembelajaran: Teori dan Konsep. Bandung: Remaja Rosdakarya Offset.

Tam, N.T.M. 2018. Using Problem-Based Learning To Promote Students' Use Of HigherOrder Thinking Skills And Facilitate Their Learning. VNU Journal of Foreign Studies, Vol.34, No.2.

Widiawati, L., Joyoatmojo, S., and Sudiyanto, S. 2018. Higher Order Thinking Skills as Effect of Problem Based Learning in the 21st Century Learning. International Journal of Multicultural and Multireligious Undestanding, Vol. 5, No. 3. 